\title{
Use of Inulin and Topinambur Food Fibers in Meat-Based System with Addition of Rabbit Meat
}

\author{
Kurchaeva Elena \\ Faculty of Veterenary Medicine \\ and Animal Husbandry Technology \\ Voronezh State Agrarian Univercity named after \\ Emperor Peter the Great \\ Voronezh, Russia \\ alena.kurchaeva@yandex.ru \\ Shencova Evgeniya \\ Technological faculty \\ Voronezh State University of Engineering Technologies \\ Voronezh, Russia \\ evgeniya-shencova@yandex.ru \\ Vostroilov Aleksander \\ Faculty of Veterinary Medicine \\ and Animal Husbandry Technology \\ Voronezh State Agrarian Univercity named after \\ Emperor Peter the Great \\ Voronezh, Russia \\ kaftchz@veterin.vsau.ru
}

\author{
Derkanosova Natalya \\ Faculty of Technology and Merchandizing \\ Voronezh State Agrarian Univercity named after \\ Emperor Peter the Great \\ Voronezh, Russia \\ kommerce05@list.ru
}

\author{
Maksimov Igor \\ Faculty of Technology and Merchandizing \\ Voronezh State Agrarian Univercity named after \\ Emperor Peter the Great \\ Voronezh, Russia \\ maximus880@mail.ru
}

\author{
Kashirina Natalya \\ Faculty of Technology and Merchandizing \\ Voronezh State Agrarian Univercity named after \\ Emperor Peter the Great \\ Voronezh, Russia \\ nat kash17@mail.ru
}

\begin{abstract}
The purpose of the article is to evaluate the approaches to topinambur dietary fibers and inulin utilization in production of emulsified meat products that favour the regulation of gastrointestinal tract processes. The methods based on maximal water and fats absorption and retention were used to evaluate functional and technological properties of dietary fibers. Standard physical chemical methods, based on water and fats retention, were used to evaluate model meat systems and the chemical composition of final product. The main approach to creating a balanced food system relies on the methodology of food system composition based on recommendations of Professor Kasyanov G.I. and Professor Lisin P.A. The efficiency of $6 \%$ topinambur dietary fibers utilization was shown to be valid when used together with functional ingredients for creating stable emulsified meat substances with high functional and technological properties. Emulsified meat product with optimal chemical and amino acid composition was designed on the basis of methodological approach. Organoleptic and physical-chemical characteristics were identified and the emulsified meat product safety was proved. The studies confirm a positive effect of dietary fiber and inulin of Jerusalem artichoke improvement for functional and technological properties of the meat system, enrichment of emulsified food product fibers of different structures, which in turn allows solving the problem of integrated approach to the use of raw materials and stabilizing quality of emulsified meat products functional orientation.
\end{abstract}

Keywords - topinambur, dietary fibers, inulin, functional and technological properties, emulsified products, nutritional value

\section{INTRODUCTION}

Modern meat processing industry significantly progressed in efficient regulation of raw material and final products properties. The experience of industrial plants and the evaluation of the supplied by different companies food supplements prove that it is beneficial to use biopolymer complex substances to obtain physiological effect.

From epy biomedical point of view, food products, enriched with dietary fibers, attract researchers' attention. It is well known that dietary fibers facilitate gastrointestinal regulation, cholesterol elimination and blood sugar level decrease. Due to water retaining properties, they accelerate intestinal transit and stimulate colonic motility, act as a factor of feces formation. Dietary fibers adsorb a significant part of bile acids and other metabolites, toxins and electrolytes, which enhances body detoxication.

Dietary fibers are not digested by human body enzymes, but they are processed by intestine beneficial microflora. Presently, dietary fibers are recognized as an essential nutritional component $[3,5]$. 
The importance of healthy diet is confirmed by numerous researches that highlight direct relation between human immune status and their diet.

Lack of dietary fibers in human diet promoted the spread of different metabolic disorders among the population, what in its turn increased the incidence of colon cancer, gallstone disease and atherosclerosis [3]. Along with nutritional science development, the range of essential nutritional components for normal life-sustaining activity was expanded. A new concept of healthy nutrition appeared. According to this concept, essential nutritional components include not only beneficial, but also ballast substances (dietary fibers).

Compared to the Decree of the Russian Federation government «The basis of state policy regarding healthy nutrition of Russian federation population until the year 2020», nutrition of most adult population fails to comply with the principles of healthy nutrition due to consumption of significant amounts of animal fats and simple carbohydrates, and lack of vegetables, fruit, fish and seafood consumption. This leads to body weight increase and obesity, which incidence increased from 19 to $23 \%$ during the past $8-9$ years, thus, promoting the risk of diabetes mellitus, cardiovascular and other diseases development [15].

All the mentioned facts stress the necessity to develop programs that will optimize population nutrition. Food and processing industries should acknowledge the necessity of such disease prevention and implement this strategic task by developing food products that will improve and protect national population health [4].

Human body receives dietary fibers due to plant products consumption, in particular, topinambur roots. Significant decrease of human energy demands in advanced industrial countries requires food energy adjustment, which is realized in smaller consumed food amounts and, thus, in consumption decrease of biologically active substances and dietary fibers. The fact that population mainly consumes manufactured products aggravates this issue. At present, the ratio of refined foods is more than $60 \%$ of the daily food consumption in advanced industrial countries. As a result, every day human body receives only $10-20 \mathrm{~g}$ of dietary fibers that are contained in plant products, together with increased amount of animal proteins and fats. Physiological need in dietary fibers, approved by the Ministry of Health of the Russian Federation, is $30 \mathrm{~g}$ /day, provided the daily energy value of the consumed food is 2500 kcal.

Dietary fibers in food products promote movement of the consumed food along the gastrointestinal tract due to improvement of digestion processes, gut motility stimulation and intestine motor function regulation. In its turn, faster movement of food along gastrointestinal tract prevents decay processes, synthesis and absorption of compounds that cause oncological diseases not only in gastrointestinal tract, but also in other organs. These compounds clearance is enhanced due to fibrous-capillary structure of dietary fibers that act as natural enterosorbents. Dietary fibers sorbing effect also helps to bind bile acids, cholesterol of atherogenic low-density lipoproteins (that lead to atherosclerotic plaques formation), endo and exotoxins, including free ammonia, radionuclides, heavy metals and other toxic compounds $[1,8]$.

Elimination of extra cholesterol promotes normalization of bile lipid components, which plays an important role in prevention and treatment of gallstone disease. Total cholesterol and cholesterol of atherogenic low-density lipoproteins decrease is important for prevention and treatment of cardiovascular diseases, that are considered to be the major cause of mortality nowadays. Dietary fibers promote elimination of harmful substances from a human body, which is particularly acute due to significant deterioration of ecologic situation.

Utilization of plant raw materials in meat production allows one not only to enrich meat products with balanced ingredients and increase nutrients accessibility but also to make products that comply with physiologic standards of nutrition [7]. In their turn, food manufacturers broaden the assortment of new products both utilizing new functional ingredients and developing new types of products. Thus, topinambur utilization attracts great practical interest. In many developed countries large-capacity food supplements industry is based on topinambur that occupies leading positions in the world food industry, competing with chicory and other cultures [16-19]. At the same time, topinambur is an easy to cultivate culture, that doesn't require pesticides application which reduces production expenses and increases the quality of food that it is produced out of.

As to tubers of Jerusalem artichoke used for industrial processing, certain requirements are imposed - the equalization of the tuber (no holes, growths), the size of the tubers ( $80-90 \%$ of the tubers in the nest should be uniform in size and have an average weight of $50-100 \mathrm{~g}$ ), "looseness" of the nest (the length of the stolons should be at least $2-5 \mathrm{~cm}$ and not more than 15 $\mathrm{cm})$. The most promising varieties should accumulate the greatest amount of multiple fruit by the time of harvesting.

Of particular interest, in terms of consumer properties, is the carbohydrate component of tubers Jerusalem artichoke - inulin, the amount of which, depending on the variety ranges from 13 to $20 \%$. Inulin $\left(\mathrm{C}_{6} \mathrm{H}_{10} \mathrm{O}_{5}\right) \mathrm{n}$ is a natural linear biopolymer consisting of d-fructose molecules linked by glycoside bonds. In the hydrolysis of inulin, D-fructose is formed. Inulin is used in food production and medicine. Inulin helps to reduce the level of cholesterol in the blood, increase the number of bifidobacteria in the colon, reduces blood sugar, lipoproteins and triacylglycerins, has a hypoglycemic effect, which is especially important for people with metabolic disorders $[5,6$, $14]$.

Consumption of sugar (sucrose) and confectionery products containing a large amount of sugar is steadily increasing, which becomes dangerous to health. Increased consumption of sucrose over the past 50 years has led to a sharp increase in the number of cases of caries, diabetes, coronary heart disease and obesity in people.

Diabetes remains one of the most pressing problems of clinical medicine. Diabetes is the third leading cause of death (6\%) after cardiovascular disease (51\%) and cancer (17\%). 
Over the past 10 years, there has been an increase in the incidence of diabetes in all countries of the world. In Russia, at least $3-5 \%$ of the population has diabetes. In the population of patients with diabetes 6-8\% are children under the age of 14 years. The annual increase in the number of children with insulin-dependent diabetes is $6 \%$. Up to $13 \%$ of children with diabetes mellitus are under 5 years old.

According to the Institute of nutrition, about $25 \%$ of the population over the age of 50 years need a full or partial replacement of sucrose with fructose.

In the gastrointestinal tract, fructose is absorbed much more slowly than glucose. This gives a great dietary advantage in the treatment of diabetes. Fructose is absorbed mainly without the influence of insulin, so blood sugar may increase slightly.

The value is represented by rhizomes of Jerusalem artichoke, which go to food, animal feed and technical processing (alcohol, fructose). Both raw and heat-treated tubers are used. Frozen tubers become sweet taste as hydrolytic decay of inulin produces fructose.

The purpose of this study is to evaluate utilization of topinambur dietary fibers in the production of balanced food products based on biomodified meat byproducts.

Nowadays, sausage production, that is characterized by great volume of production output and intensive technologies, along with main raw materials utilizes different plant and animal supplements. The supplements possess high nutritional value and functional properties that improve or stabilize the quality of ready products; they are cheap, storage stable and easy to use in minced meat compositions. It should be noted that the amount of the introduced additives should be based on the quality aspects of the produced foods.

Slaughterhouse byproducts occupy significant part of meat processing industry. According to the All-Russian Research Institute of Meat Industry, the ratio of $1^{\text {st }}$ category meat byproducts is $3 \%$ and of $2^{\text {nd }}$ category is $7 \%$ to the cattle live weigh [11]. Chemical composition of meat byproducts, that are used in production of complex composition foods, are characterized by quite high protein content (from $10.0 \%$ to $19.7 \%$ ), for example bovine cattle udder (12.9\%), but they are not widely used in meat industry because of relatively low functional and technological properties. Thus, utilization of byproducts that underwent microbal biotransformation will allow proving the practicability of this raw material source utilization in production of complex meat products composition.

\section{MATERIALS AND METHODS}

The object of the study is topinambur dietary fibers and emulsified food compositions based on plant and animal raw materials. Animal raw material was used as mince meat sample based on mince meat made of bio modified bovine cattle udder and $2^{\text {nd }}$ category beef meat and rabbit meat.

Rabbit meat is a dietary raw meat, characterized by pale pink color, rather delicate texture and different fine-fibrous muscle tissue. The amount of connective tissue in the meat of the rabbit is small, so it is characterized by a gentle consistency.
Rabbit meat contains a lot of nitrogenous, mineral (acid salts of phosphorus (246 $\mathrm{mg} \%$ ) and potassium (364 mg\%). The presence of extractives gives the meat a specific smell and taste. The cholesterol content of rabbit meat is $25 \mathrm{mg}$ per $100 \mathrm{~g}$ of meat.

Topinambur dietary fibers and inulin were used to enrich mince meat sample according to requirements of TU 9112-00497357430-09 («Ryazanskiye Prostory», LLC. Ryazan Oblast, Sapozhok, certificate № 62.РЦ.03.009.У.000009.06.09 dated 2009.06.24) [19]. Dietary fibers, contained in topinambur, is a big heterogeneous polysaccharide group that consists of a mix of cellulose and hemicellulose that can absorb and retain water. Previously dehydrated topinambur dietary fibers were added to the mincemeat sample in the amount of $0-15 \%$ in the ratio of $1: 3$. Experiments were carried out in the scientific research laboratory at the Department of storage techniques and agricultural products processing at the Voronezh State Agrarian Academy. The evaluation of functional and technological properties of dietary fibers contained in mincemeat sample and chemical composition of the obtained meat product was carried out according to physicochemical methods [2]. The identification of general chemical composition was done by means of test sample single weight method, which involves consequential instrumental identification of moisture, fats, ashes and protein content in one sample weight with a device for express identification of moisture and fats content in meat products [2]. Weight fraction of dietary fibers was identified by gravimetric method according to the requirements of GOST R 54014-2010. The method is based on enzymic hydrolysis of starch and non-starch compounds with the help of a-amylase, protease and amyloglucosidase into mono-, di- and oligosaccharides and peptides. Dietary fibers were exposed to ethanol, dried out and underwent gravimetric test. Total weight fraction of dietary fibers is expressed as percentage $(\mathrm{g} / 100 \mathrm{~g})$.

Organoleptic evaluation of the product was done by the testing group of people based on a 5 point scale. Organoleptic evaluation had to identify main quality factors compliance with the requirements (what the sample looks like outside and at the place of cutoff, smell, taste and consistence).

The methodology of the food mixture composition design was based on the guidelines outlined in the works of Professor Kasyanov G.I. and Professor Lisin A.P. [12, 13]. Statistical analysis of the calculated data was carried out by the software STATISTICA 6.0 [13].

Mincemeat made of bovine cattle udder was exposed to a set of microorganisms based on such preparations as "Bifidum №791 BAG” (bifidumbacterium.bifidum №791BAG, bifidumbacterium.bifidum 8-3 and bifidumbacterium.longum, "Biocor" LLC, Russia) and Staphylococcus carnosus M III, Lactobacillus sakei ("BACTOFERM F-SC-111", "Chr. Hansen GmbH", Giessener Str. 94) taken in a 1:3 proportion and added in the dose of $5 \%$ to the weight of initial raw material. Biomodification was carried out at $22 \pm 2^{\circ} \mathrm{C}$ during 6 hours.

Red palm oil «Carotino» was used as a source of polyunsaturated fatty acids. Red palm oil has bright orange colour, which is explained by a high content of carotinoids, pleasant smell and taste and is highly resistant to oxidation. Palm oil is easily digested, absorbed and metabolized. It 
supplies human body with energy and essential fatty acids. Palm oil contains carotinoids; their content is $100-120 \mathrm{mg} / 100$ g. It is well known that they are precursors of vitamin A, which is contained only in animal fats. Apart from carotinoids, palm oil contains around $80 \mathrm{mg} / 100 \mathrm{~g}$ of tocopherol and tocotrienol complex and $0.43 \mathrm{mg} / 100 \mathrm{~g}$ of coenzyme $\mathrm{Q}_{10}$. Among palm oil fat acids there are myristic, palmitic, palmitolic, stearinic, oleinic, linoleic and arachidonic acids [10].

Milk protein "Anisomin" utilization improves functional and technological meat products properties and creates spreadable structure, which provides highly emulsified consistence of mince meat [9].

Paramecium caudatum (free living, easily cultivated singlecelled organism) was used as a test object for express bio test. Express bio test is quite sensitive to active substances contained in testing objects and shows their association with organism viability.

Product sample weight is dried at the temperature not higher than $30^{\circ} \mathrm{C}$ until its weigh stabilizes. The $10 \mathrm{~g}$ weight sample is milled if necessary, sieved through 72-gauge mash for obtaining particles not bigger than 225 micron. After that, 3 samples $1 \mathrm{~g}$ each are taken from the weight sample and placed into $10 \mathrm{~cm}^{3}$ of distilled water. The mixture stands for 24 hours; after that it is shaken and centrifuged. For further research the centrifugate is used, that contains the diluted test substance in 1:10 ratio.

Express bio test includes stages: I stage - evaluation of test objects biological activity. $9.9 \mathrm{~cm}^{3}$ of infusorium culture is placed into test tubes. $0.1 \mathrm{~cm}^{3}$ of distilled water is poured into the control probe tube. $0.1 \mathrm{~cm}^{3}$ of centrifugate of the tested substance is poured into the test probe tube. The obtained ratio is $1: 1000$. The probes with diluted test objects 1:10,000; $1: 100,000 ; 1: 1,000,000$ are prepared.

Infusoria status is estimated after $0.5,1.0,3.0,6.0$ and 24.0 hours of cultivation at $25^{\circ} \mathrm{C}$. Infusoria status is estimated by the quality and character of infusoria movements by the following criteria: IN - indifference - the cells are involved into uniform Brownian movements; BA - bioactivity - the cell movements are changed; (BC - biocidity, toxic effect: $\mathrm{BC}-50-50 \pm 10 \%$ of cells were killed, BC- $100-90 \pm 10 \%$ of cells were killed (1:1,000 dilution - the object causes light toxic effect, $1: 10,000$ dilution - mild toxic effect, 1:100,000 - strong toxic effect, $1: 100,000$ - severe toxic effect).

II stage - evaluation of biological activity of the tested objects by means of the method of intentional exposure. The method is based on the identification of the test object biological effect on the adaptation mechanisms and cells resistance with the help of additional adverse factor.

Infusoria culture from the $1^{\text {st }}$ stage is used that contacted with different concentrations of the test object within 24 hours. The test identified the time of $100 \%$ cells death under the exposure of $8 \%$ sodium chloride solution.

Reproduction rate index at $I=1.000 \pm 0.100$ shows that the object is biologically inactive, at $I>1.000 \pm 0.100$ - the object stimulates cells reproduction, at $I<1.000 \pm 0.100$ - the object inhibits cells reproduction. The reproduction rate index value, together with object concentration in media, characterizes the degree of its influence on the reproduction mechanism.

The methods of mathematical modelling and programming were used for designing balanced pate compositions for optimization of amino acids content in the product. Algorithms of "simplex criterion" were used for liner and integral-valued problems solution with limitations. To realize mathematical plans, amino acid score was used as a target function; the ratio of protein containing components, included into the pate composition, varied. To solve the problem of optimization, we minimized the sum of discrepancies between the real amino acid ratio in proteins of the designed product and their proportion in the "ideal protein" for each amino acid.

\section{RESULTS AND THEIR DISCUSSION}

Due to the shortage of animal protein in the world, the needs of the population are met by other sources. The increase in demand for protein products in the future, on the one hand, and the need to ensure a rational diet - on the other, led to the emergence and rapid development of a qualitatively new direction in food production. It consists in the production of combined food products based on significant potential resources of plant and animal origin.

Currently, much attention is paid to the development of functional additives prebiotic orientation based on plant composites, rich in physiologically active ingredients. In this aspect, special attention is paid to the products of processing of Jerusalem artichoke.

Modern high-efficiency methods of deep processing of vegetable raw materials are of paramount importance for solving food, fuel and energy and environmental problems. Currently, the main trends of the world food market include the rapidly developing industry of functional food products based on meat, which deservedly enjoys the interest of consumers. The relevance of a healthy diet is confirmed by studies indicating a direct relationship between the immune status of a person and the food they eat.

Meat products are considered to be the most widespread food products. To balance the chemical composition and to enrich the designed product with biologically active substances according to the requirements of healthy nutrition, we used minced meat based on biomodified bovine udder and the $2^{\text {nd }}$ category beef meat, meat of rabbits in 1:1:2 ratio. The used set of microorganisms allows one to improve functional and technological properties of bovine cattle udder: water binding capability (WBC) increases from 41.3 to $62.8 \%$, water retaining capability (WRC) increases from 42.3 to $62.5 \%$, and thus, to broaden the possibility of its utilization in meat food production. The mix of biomodified bovine cattle udder and the $2^{\text {nd }}$ category beef meat in the chosen ratio allowed one to design minced meat sample that is characterized by high functional and technological properties: WBC 71.4\% and WRC 75.7\%.

Topinambur dietary fibers, used for enrichment of minced meat sample, are characterized by the following functional and technological properties (FTP): WRC is $8.04 \pm 0.05 \mathrm{~g}$ of water $/ \mathrm{g}$ of the sample and fat retaining capability (FRC) is $4.69 \pm 0.05 \%$ $\mathrm{g}$ of fat $/ \mathrm{g}$ of sample. The data confirms high values of water and fat retaining capability, which will help to stabilize emulsified 
meat. When topinambur dietary fibers and inulin (1:1) were added, functional and technological properties of the minced meat sample (WBC, WRC, FRC) increased from 65.7; 69.8; $62.7 \%$ to $74.9 ; 74.6 ; 75.6 \%$, respectively, the maximum values were obtained at the dose of $6 \%$ of hydrated complex (1:5) to the total sample minced meat weight. Further dilution of the sample with water leads to insignificant decrease of all functional and technological properties (FTP) of the minced meat sample that doesn't contain plant supplements. The improvement of minced meat functional performance is probably associated with the increase of high-molecular compounds content in the designed sample, which can increase binding and retaining moisture capability. The complex of milk protein and topinambur of products contains such high-molecular compounds as proteins and polysaccharides.

The chosen dosage and ingredient ratio were used for the design of the emulsified meat product based on the matrix approach compounds estimations, and preferable set and ratio of components were based on the mass conservation law and theoretical grounds of linear programming.

TABLE I. COMPOSITION OF “SELSKII” PATE

\begin{tabular}{|l|c|}
\hline \multicolumn{1}{|c|}{ Component } & Weight, $\mathbf{~ k g / 1 0 0 g}$ \\
\hline $2^{\text {nd }}$ category beef meat & 17.25 \\
\hline Biomodified bovine cattle udder & 17.25 \\
\hline Meat of rabbits & 34.50 \\
\hline Trimmed bovine liver & 16.00 \\
\hline $\begin{array}{l}\text { Hydrated topinambur dietary fibers } \\
\text { inulin of Jerusalem artichoke } 1: 1\end{array}$ & 6.00 \\
\hline Sauteed onion & 2.50 \\
\hline Blanched carrots & 3.00 \\
\hline Palm oil Carotino & 1.50 \\
\hline Milk protein Anisomin & 1.50 \\
\hline Salt & 0.50 \\
\hline Total & 100.00 \\
\hline
\end{tabular}

TABLE II. NUTRITIONAL AND BIOLOGICAL VALUES OF THE DESIGNED PATE

\begin{tabular}{|l|c|}
\hline Values & "Selskii " pate \\
\hline Moisture, \% & 70.80 \\
\hline Protein, \% & 13.50 \\
\hline Fat \% & 6.50 \\
\hline Carbohydrates, \%, & 9.00 \\
including dietary fibers & 6.50 \\
\hline Ashes, \% Amino acids, g/100g of protein \\
\hline \multicolumn{2}{|c|}{1.20} \\
\hline Leucine & 7.20 \\
\hline Isoleucine & 4.90 \\
\hline Lysin & 7.40 \\
\hline Methionine + cystine & 4.20 \\
\hline Phenylalanine + tyrosine & 6.60 \\
\hline Threonine & 4.12 \\
\hline Tryptophane & 1.50 \\
\hline Valine & 4.10 \\
\hline
\end{tabular}

The composition of the designed emulsified product "Selskii" pate is described in Table 1. The quality values of the "Selskii" pate are listed in Table 2.

The designed emulsified product has spreadable pasty texture, attractive appearance (colour of mince meat from beige to pink, grayish shade is possible), original smell and optimal salty taste, that is peculiar to this product type. The analysis of the emulsified product chemical content showed that the product is characterized by relatively high protein content $(13.5 \%)$, low fat content $(6.5 \%)$, essential amino acids balance $(40.02 \mathrm{~g} / 100 \mathrm{~g}$ of protein) and is enriched by dietary fibers $(6.5 \%)$. Emulsified product output at $6 \%$ replace of meat source with topinambur dietary fibers was $110 \%$, which is explained by the composition of topinambur dietary fibers and their interaction with milk protein «Anisomin», that is characterized by hydrocolloid properties.

The safety test results showed that the test sample has a higher cells reproduction rate index in comparison with the control sample, which influenced on the viability of single celled organism Paramecium caudatum.

The results of emulsified products safety evaluation on singled cell organism Paramecium caudatum are shown in Tables 3 and 4 .

TABLE III. CELLS REPRODUCTION RATE INDEX CHANGE DEPENDING ON THE OBJECT RATIO

\begin{tabular}{|c|c|c|c|}
\hline \multirow{3}{*}{ Sample } & \multicolumn{3}{|c|}{ Cells reproduction rate index } \\
\hline & \multicolumn{3}{|c|}{ Object ratio } \\
\hline & $1: 100$ & $1: 1,000$ & $1: 10,000$ \\
\hline $\begin{array}{l}\text { "Selskii " pate } \\
\text { (test sample) }\end{array}$ & 0.735 & 0.780 & 0.870 \\
\hline $\begin{array}{l}\text { "K zavtraku" pate } \\
\text { (control sample) }\end{array}$ & 0.615 & 0.719 & 0.852 \\
\hline \multicolumn{4}{|c|}{$\begin{array}{l}\text { CRRI - Cells reproduction rate index } \\
\text { CRRI - } 1.0 \text { - the object is biologically inactive; }\end{array}$} \\
\hline \multicolumn{4}{|c|}{$\begin{array}{l}\text { CRRI }->1.0 \text { - the object stimulates cells reproduction } \\
\text { CRRI }-<1.0-\text { the object inhibits cells reproduction. }\end{array}$} \\
\hline
\end{tabular}

TABLE IV. BIOLOGICAL ACTIVITY CHANGE INDEX DEPENDING ON THE OBJECT RATIO

\begin{tabular}{|c|c|c|c|}
\hline \multirow{2}{*}{ Sample } & \multicolumn{3}{|c|}{ Biological activity index } \\
\cline { 2 - 4 } & $\mathbf{1 : 1 0 0}$ & $\mathbf{1 : 1 , 0 0 0}$ & $\mathbf{1 : 1 0 , 0 0 0}$ \\
\cline { 2 - 4 } & 1.56 & 1.59 & 1.84 \\
\hline $\begin{array}{c}\text { "Selskii " pate (test } \\
\text { sample) }\end{array}$ & 1.26 & 1.26 & 1.21 \\
\hline $\begin{array}{c}\text { "K zavtraku" pate } \\
\text { (control sample) }\end{array}$ & \multicolumn{3}{|c|}{ BAI - Biological activity index } \\
BAI - 1.0 - the object is biologically inactive; \\
BAI - > 1.0 - the object increases cells viability; \\
BAI - < - the object decreases cells viability.
\end{tabular}

At the ratio of 1:10,000 the test sample showed some stimulatory effect on the test object. Thus, the investigation results showed that the emulsified product does not have toxic effect on the test object, and as a result, appears to be safe for human use.

\section{CONCLUSION}

The results of the present investigation confirmed positive influence of topinambur composite mixture on the increase of functional and technological properties of mincemeat sample based on biomodified bovine cattle udder and topinambur composite mixture on the basis of food fibers and inulin from topinambur in the emulsified meat product. This, in its turn, allows one to provide complex approach to the raw material source utilization and stabilization of balanced emulsified meat products quality. Proved optimal dosage of the composite mixture to the mass of raw meat, which amounted to 
$6.0 \%$ during an increase of all functional and technological characteristics of meat systems. The developed emulsified product possesses increased food and biological value and can be recommended for using in food diet of all groups of population.

\section{References}

[1] R.I. Shazzo, R.A. Gish, R.I. Ekutech, E.P. Korneva, V.G. Kaishev,"Topinambur: biology, agricultural techniques of cultivation, its place in ecosystem, processing technologies (yesterday, today, tomorrow) [Topinambur: biologiya, agrotekhnika vyraschivaniya, mesto $\mathrm{v}$ ecosisteme, tekhnologiya pererabotki (vchera, segodnya, zavtra)," Krasnodar, 2013, 184 p.

[2] L.V.Antipova, I.A. Glotova, "Methods of evaluation of meat and meat products," M., 2007, $346 \mathrm{p}$.

[3] M.P. Mogilnyi, T.V. Shlenskaya, M.K. Galyukova, T.Sh. Shalmatyev, A.U. Balasenyan, "Current trends of dietary fibers utilization as functional ingredients," New technologies, №1, pp.27-31, 2013

[4] S.I. Khvylya, Gabaraev A.A., Pchelkina V.A, "Structural peculiarities of wheat fibers for meat products," Technologies of food production, №2 (29), P.71-75, 2013

[5] E.A.Rechkina, G.A.Gubanenko, A.I. Mashanov "Perspectives of dietary fibers utilization in food industry," Journal of Krasnodar State Agrarian University, №1, pp.91-97, 2016.

[6] A.G.Vershinina, T.K. Kalenik, O.N. Samchenko, "Development of meat and plant pate for healthy nutrition,'Technologies of food production, №1 (24), pp.120-124, 2012.

[7] "The norms of physiological requirements in energy and nutrients for different population groups in Russian federation," Section «Healthy nutrition»: MP 2.3.1.2432-08, Introduction 18.12.2008, M.: Standards publication, 2008. $-38 \mathrm{p}$.

[8] V.V. Titok et al., "Biological potential of topinambur as a raw material for food and pharmaceutical industry," BSTU publications, № 4:Chemistry, technology of organic substances and biotechnology, pp. 187-193, 2014

[9] A.V. Morgunova, L.A. Borisenko, S.A. Emeliyanov, "Innovative methods of dry protein products hydration in food industry," Agroindustrial Journal of Stavropolie, № 1 (13), pp. 57-61, 2014
[10] E.A. Tyschenko, L.V.Tereschyuk, E.G.Pavelieva, "Investigation of composition and properties of red palm oil that is used as a functional component in emulsified creams," Technologies of food production, T. 16, № 1, pp. 43-46, 2010.

[11] O.A. Kovaleva, L.V.Schulgina, "Livestock byproducts as raw material for new types of canned foods," Engineering and industrial technology sciences - from theory to practice, № 38, pp. 100-104, 2014.

[12] G.I. Kasyanov "The peculiarities of composition design of products for gerontologic population nutrition," Scientific works of Kuban State Technological University, № 10, pp. 174-186, 2016.

[13] http://www.statosphere.ru/books-arch/statistica-books/87-statistica--.html (Date of request 22.11.2017).

[14] L.E. Martemiyanova, Y.A. Zadvornov, "Composition variation of sausages containing plant components made by computer modelling method,” OmSAU Journal, №3(23), pp. 225-230, 2016.

[15] http://www.garant.ru/products/ipo/prime/doc/12079847/ Russian Federation Government Decree dated October 25th 2010, N 1873-p « The basis of state policy regarding healthy nutrition of Russian federation population until the year 2020».

[16] J. Barta ,G. Pátkai, "Chemical Composition and Storability of Jerusalem Artichoke Tubers," Acta Alimentaria, Vol. 36, №. 2, pp. 257-267, 2007, DOI: 10.4236/ajps.2013.48197

[17] M.A. Rodrigues, L. Sousa, J.E., "Cabanas Arrobas Tuber Yield and Leaf Mineral Composition of Jerusalem Artichoke (Helianthus tuberosus L.) Grown under Different Cropping Practices," Spanish Journal of Agricultural Research, Vol. 5, №. 4, pp.545-553, 2007. DOI: $10.5424 / \mathrm{sjar} / 2007054-275$.

[18] R. Slimestad, R. Seljasen, K. Meijer, S. L. Skar, "Norwegian-Grown Jerusalem Artichoke (Helianthus tuberosus L.): Morphology and Content of Sugars and FructoOligosaccharides in Stems and Tubers," Journal of the Science of Food and Agriculture, Vol. 90, pp. 956-964. 2010. DOI: $10.1002 /$ jsfa.3903

[19] S. Terzic, M. Zoric, J. Atlagic, I. Maksimovic, T. Zeremski, B. Dedic, "Classification of Jerusalem Artichoke Accessions by Linear Discriminant Analysis of Mineral Concentration in Tubers and Leaves," //Helia, Vol. 34, №. 55, pp. 83-90, 2011DOI: 10.2298/HEL1155083T 